\title{
Integrating seismic acoustic impedance inversion and attributes for reservoir analysis over 'DJ' Field, Niger Delta
}

\author{
Ayodeji Alabi $^{1}$ () Pius Adekunle Enikanselu ${ }^{1}$
}

Received: 8 November 2018 / Accepted: 25 June 2019 / Published online: 1 July 2019

(c) The Author(s) 2019

\begin{abstract}
Structural interpretation and inversion analysis were used to characterize hard-to-image reservoirs, to predict subsurface interwell reservoir properties for optimum reservoir heterogeneity description, and to fine-tune drilling locations in 'DJ' Field, Niger Delta. Post-stacked 3D seismic data, composite well logs, and velocity checkshot data were used for the reservoir analysis. The study entailed mapping of structural framework, horizon picking, wavelet extraction, log editing and correlation, building of low-frequency model, acoustic impedance inversion and crossplot analysis of reservoir properties. Four major antithetic, three regional, and five minor faults were identified. The inversion results revealed an acoustic impedance range of $9700-25,000 \mathrm{ft} / \mathrm{s} \mathrm{g} / \mathrm{cc}$ and porosity range of $25-45 \%$ within the hydrocarbon-bearing sands. Crossplot analysis of Poisson and $\mathrm{Vp} / \mathrm{Vs}$ ratio against acoustic impedance revealed Poisson ratio range of $0.30-0.45$ and $V_{\mathrm{p}} / V_{\mathrm{s}}$ ratio range of $1.3-2.50$ within the delineated hydrocarbon-bearing sandstone interval. The overall correlation coefficient between the inverted and actual impedance was about $98 \%$ across the eight wells. Acoustic impedance slice at $2300 \mathrm{~ms}$ revealed low acoustic impedance sand within the range of 13,000-24,000 ft/s g/cc at the western and central part of the field. Comparing the acoustic impedance slice and seismic attribute maps at the target reservoir zones revealed high reflection amplitudes (bright Spots), indicative of hydrocarbon accumulation. The study predicts new and reliable drillable locations, by lithologic/fluid discrimination in the analysis of delineated reservoirs in the study area.
\end{abstract}

Keywords Porosity $\cdot$ Lithology $\cdot$ Seismic attributes $\cdot$ Acoustic impedance

\section{Introduction}

Reservoir analysis describes the reservoir characters qualitatively and quantitatively using seismic and well data. The process includes delineation, description, and reservoir monitoring. Reservoir delineation accounts for the reservoir geometry, including the faults and facies changes which can affect the reservoir production performance. Reservoir description defines the reservoir physical properties such as the porosity, permeability, water saturation, pore fluid (Sukmono 1999).

On the other hand, seismic inversion involves creating subsurface geological model using seismic data as input and

Ayodeji Alabi

dejialabi@yahoo.com

Pius Adekunle Enikanselu pa.enikanselu@futa.edu.ng

1 Department of Applied Geophysics, Federal University of Technology, Akure, Nigeria well data as control. This inversion for reservoir analysis reads between the lines or between reflecting interfaces to produce detailed models of rock properties (Schlumberger 2008). Acoustic impedance (AI) volume has many advantages for reservoir delineation and description because it is obtained by integrating data and is closely related to rock properties (Latimer et al. 2000). The ultimate goal of seismic inversion procedure, in this context of reservoir analysis, is to provide models not only of acoustic impedance but also of other relevant physical properties, such as porosity, Poisson ratio, and $\mathrm{Vp} / \mathrm{Vs}$ ratio, around the well. Usually, at well locations, we have measurements that give us a good idea of the elastic and physical properties of the subsurface rocks such as lithology, porosity, density. To understand these properties away from well, the lateral and vertical variation can be inferred via rock physics studies (Sayers and Chopra 2009). Such quantitative interpretations may sometimes require the use of other seismic attributes in addition to the traditional seismic reflection amplitudes (Rijks and Jauffred 1991; Lefeuvre et al. 1995; Russell 2004; Sancevero et al. 2005; 
Soubotcheva 2006). There is therefore the need to combine conventional seismic interpretation and inversion analysis to successfully resolve the problem of prospect evaluation. Seismic data may be inspected and interpreted on its own without inversion. However, this does not provide the most detailed view of the subsurface and can be misleading under certain conditions (Pendrel 2006). For instance, not all closures identified on seismic structure maps are hydrocarbonbearing. This research is thus aimed at integrating seismic acoustic impedance inversion and structural interpretation for reservoir analysis of the study area, with its objectives geared towards characterizing hard-to-image reservoirs, predicting reservoir properties away from well logs, describing the reservoir heterogeneity, and fine-tuning drilling locations. The interpretation of these geophysical study techniques increases the confidence in correct ranking of leads/ prospect (e.g. Veeken et al. 2002). Such an approach reduces uncertainties and drilling risks, an important aspect for optimizing an exploration development strategy.

\section{Location and geology}

The study area as shown in Fig. 1 is located between latitudes $5^{\circ} \mathrm{N}$ to $7^{\circ} \mathrm{N}$ and longitudes $7^{\circ} \mathrm{E}$ to $9^{\circ} \mathrm{E}$ in the southeastern part of Niger Delta. This region is bounded by the Gulf of Guinea and in the north by older Cretaceous elements such as the Anambra Basin, Abakaliki Uplift and Afipko Syncline. The lithostratigraphic sequence of the Niger Delta is the Akata, Agbada, and Benin Formation (Avbovbo 1978; Doust and Omatola 1990a, b). The sedimentation type within the area is paralic sand and shale sequences. The Agbada Formation underlies the Benin Formation and is the major petroleum-bearing unit. It was laid down in paralic brackish to marine fluviatile, coastal environments. In the lower Agbada Formation, shale and sandstone beds were deposited in equal proportions; however, the upper portion is mostly sand with only minor shale interbeds. It is made up mainly of alternating sandstone, silt and shale.

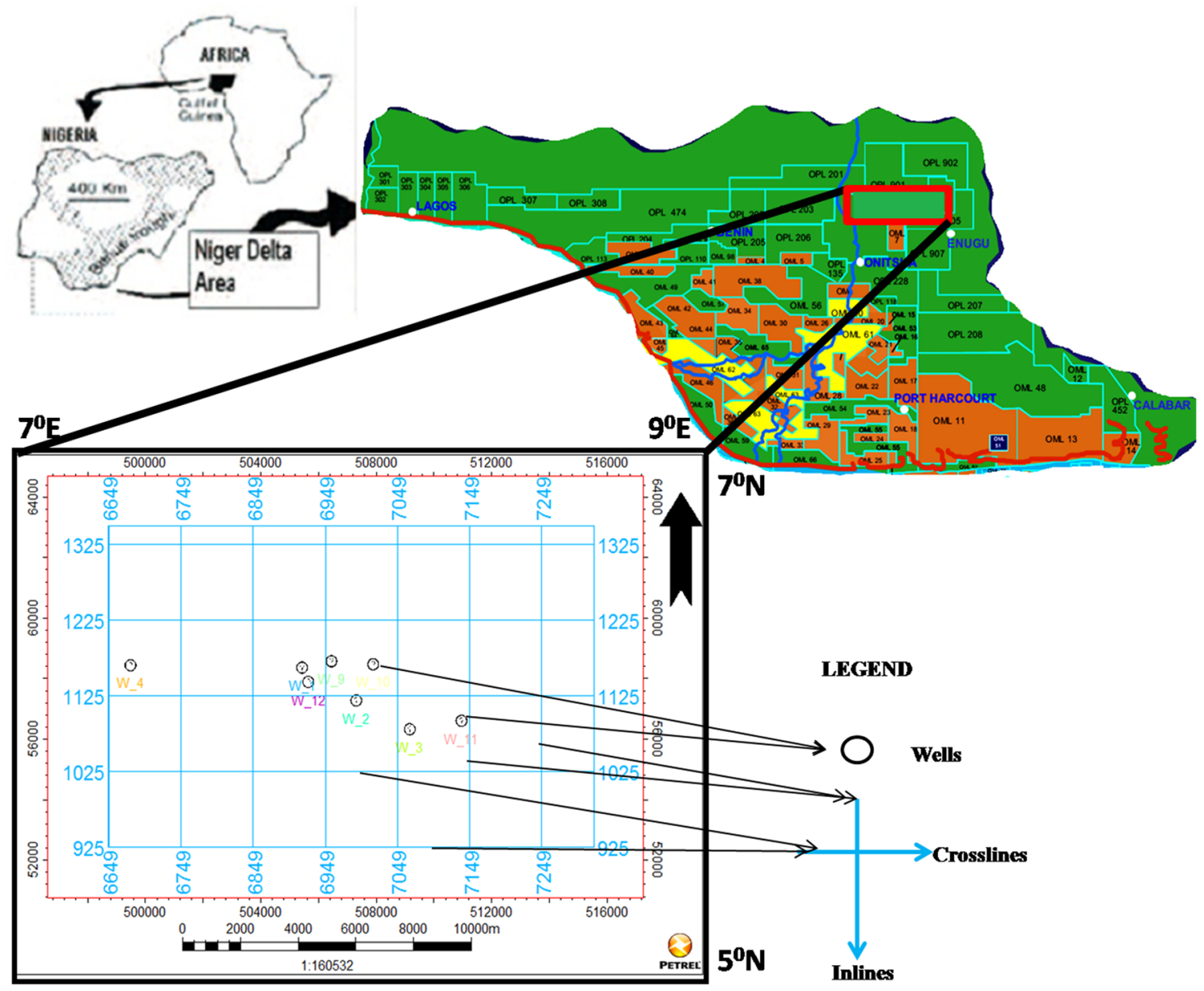

Fig. 1 Location of the study area and the base map showing the seismic lines 


\section{Type of studied sandstone}

Petroleum in Niger Delta is produced from sandstone and unconsolidated sands predominantly in the Agbada Formation. Characteristics of the reservoirs in Agbada Formation are controlled by depositional environment and by depth of burial. Known reservoir rocks are Eocene to Pliocene in age and are often stacked, ranging in thickness from less than $15 \mathrm{~m}, 10 \%$ having greater than $45 \mathrm{~m}$ thickness (Evamy et al. 1978). The thicker reservoirs likely represent composite bodies of stacked channels (Doust and Omatsola 1990a, b). Based on reservoir geometry and quality, Kulke (1995) describe most important reservoir types as point bars of distributaries channels and coaster barrier bars intermittently cut by sand-filled channels. Edwards and Santogrossi (1990) describe the primary Niger Delta reservoirs as Miocene paralic sandstones with $40 \%$ porosity, 2 Darcy's permeability, and a thickness of $100 \mathrm{~m}$. The lateral variation in reservoir thickness is strongly controlled by growth faults: the reservoir thickness towards the fault within the down-thrown block (Weber and Daukoru 1975). The grain size of the reservoir sandstone is highly variable with fluvial sandstone tending to be coarser than their delta front counterparts.

\section{Mineralogy and the digenetic history of the studied sandstone}

In the Agbada Formation of Niger delta, diagenetic modifications to the sandstones are largely controlled by chemical factors. However, in other to fully understand these processes, it is also necessary to consider the physical changes that take place before and sometimes simultaneously with them. Physical diagenesis affects the sediments more in their early stages of burial but may continue until the late stages. The processes of physical diagenesis include the rearrangement of grains (particularly mica and clay particles), grain fracturing, grain bending, and grain squeezing.

Lambert (1981) carried out detailed petrological analyses of the sediments of the Agbada Formation to determine their diagenetic history and explain their underconsolidation. $\mathrm{He}$ discovered that the sandstones are poorly cemented quartz arenites containing a small quartz and clay matrix as well as a small amount of carbonate cement. The reasons for the inadequate supply of cementing materials were also investigated. Early calcite cementation inhibited compaction and resulted in poor packing and later removal of this calcite generated secondary porosity at depth. The effect of burial diagenesis on the clay assemblages of the shale and sandstones of the Agbada Formation is limited, and the clay mineralogy is predominantly a detrital assemblage. Compared to the hydrocarbon reservoir sandstones, the non-hydrocarbon reservoirs are richer in authigenic minerals, namely kaolinite, smectite, siderite, and pyrite. The discussion of the diagenesis of the Agbada Formation has shown that both physical diagenesis (compaction) and chemical diagenesis (cementation, alteration, and dissolution) have each not reached very advance stage in the Niger Delta. The sum total of the events is that compaction with sandstone of similar characteristics in the Gulf Coast (Heald 1956; Burst 1969; Al-Shaieb et al. 1980) and those of Agbada Formation possesses higher porosities. The higher porosities of this sandstone largely result from the development of secondary porosity by dissolution of the early precipitated calcite. Log-derived porosities for the Niger Delta show that porosities of $25-30 \%$ are common at burial depths of 2745-3050 m. Pryor (1973) has shown that modern beach and channel sands similar to those that may have given rise to the sandstone of the Niger Delta possess initial depositional porosities of $40-50 \%$.

\section{Methodology}

The project workflow involved two phases: structural mapping and seismic acoustic impedance inversion. Reservoir geometry and the structural framework of the reservoirs were delineated by tracking seismic reflection events on the seismic volume. Seismic to well tie was also carried out to tie the well and seismic data for horizon picking. Three horizons were picked across the seismic volume and imported to the inversion workflow to guide the process. Statistical and well wavelet extraction were carried out within a time window to extract a zerophase wavelet from the seismic and well logs. The reflectivity was convolved with the zero-phase wavelet from the seismic data to generate a synthetic trace for log correlation. This process aligned the synthetic calculated from the well logs with one or more seismic traces near the well locations. As a prior information and input into the inversion, an initial model $(I)$ was generated from density $(\rho)$ and P-wave $\left(V_{\mathrm{p}}\right)$ velocity $\log$ using equation: $I=\rho * V_{\mathrm{p}}$.

To avoid high-frequency interference with the inversion result from the well data, a low-pass filter was applied. The final 3-D volume inversion was carried out using the generated model, horizons, and well logs together with extracted wavelet as input parameters. The predicted and original impedance curves were compared via inversion analysis. Crossplot analysis was carried out to establish the relationship between the seismically measured acoustic impedance, porosity, and other reservoir properties derived from the wells. The execution of these steps was done with the aid of Schlumberger Petrel Seismic to simulation software and Hampson-Russell inversion software. 


\section{Sources of the information regarding porosity values (how it is measured)}

Porosity may be determined by various methods. Some are based on core samples; others are based on well-log data and mathematical models. Of particular interest are techniques of porosity estimate from transit time analyses that make use of interval velocities obtained from seismic traces. It is expected that acoustic impedance $\left(V_{\rho}^{*} \rho\right)$ shows some correlation with porosity as proposed by Raymer et al. (1980) and the relationship between porosity and velocity is as follows:

$V_{\rho}=\left((1-\varphi)^{2} * V_{\rho \text { SOLID }}\right)+\left(\varphi * V_{\rho \text { FLUID }}\right)$,

where $V$ is the velocity and $\varphi$ is porosity. The mass balance density porosity equation is equally well known:

$\Phi=\left(\rho_{\text {Log }}-\rho_{\text {FLUID }}\right) /\left(\rho_{\text {MATRIX }}-\rho_{\text {FLUID }}\right)$,

where $\Phi$ is porosity and $\rho$ is density.

Patchett and Coalson (1982) determined that the density log is the most accurate method to determine porosity when one has knowledge of grain density and fluid density. While this method is standard in production wells, these parameters are often unknown for wildcats. Grain density can change rapidly along the borehole as lithology changes. Fluid types and saturations change more slowly, except fluid contacts. Thus, we have four unknowns-porosity, grain density, hydrocarbon saturation, and water saturation, and one measurement - bulk density. A statistical method is used to combine the environmentally corrected log readings from the density, neutron, acoustic, and gamma ray to solve for the four unknowns. Often, shallow resistivity $\log$ is included in the mix, and the acoustic log is dropped.

\section{Results and discussion}

\section{Structural interpretation}

Figure 2 reveals that the field is structurally characterized by synthetic (F3, F8, F13) and antithetic faults (F9, F12, F1). Combination of these two sets of listric growth faults results in features that include collapsed crests, back to back, large and steeply dipping regional flank. About twelve faults were mapped across the 3D seismic volume. These faults are regularly spaced and rotational. Three major regional faults (F1, F2, and F3) and five minor faults (F4, F6, F7, F10, and F11) were identified. Four of the faults are antithetic and dips landwards to the continent, while the rest are synthetic faults. Figure 3 shows the time structural map of horizon 1 ranging from -2160 to $-2910 \mathrm{~ms}$ with contour interval of $30 \mathrm{~ms}$. The features delineated revealed areas of structural high or anticline at the northern part trending east-west and structural low at the south-western part of the map.

\section{Model-based inversion}

Figure 4 shows the model-based inversion result with a composite gamma ray, deep resistivity, and density logs from well 1. It revealed the delineated hydrocarbon-bearing sand between the depths $8250 \mathrm{ft}$ and $8415 \mathrm{ft}$. The sand body is of low acoustic impedance range of $9700-17,900 \mathrm{ft} / \mathrm{s} \mathrm{g} / \mathrm{cc}$ as compared to the adjacent shale which is of higher acoustic impedance. Figure 5 shows a time slice of acoustic impedance at $2180 \mathrm{~ms}$ within the sand body. The regions of low impedance are encircled (L1 and L2). This resistive, low acoustic impedance is indicative of fluid-saturated sand (hydrocarbon). Most wells drilled (e.g. W_4, W_12, W_2, and W_3) were located around this region. Figure 6 shows a composite plot
Fig. 2 Typical seismic section (inline 7216) showing structural configuration of 'DJ' Field

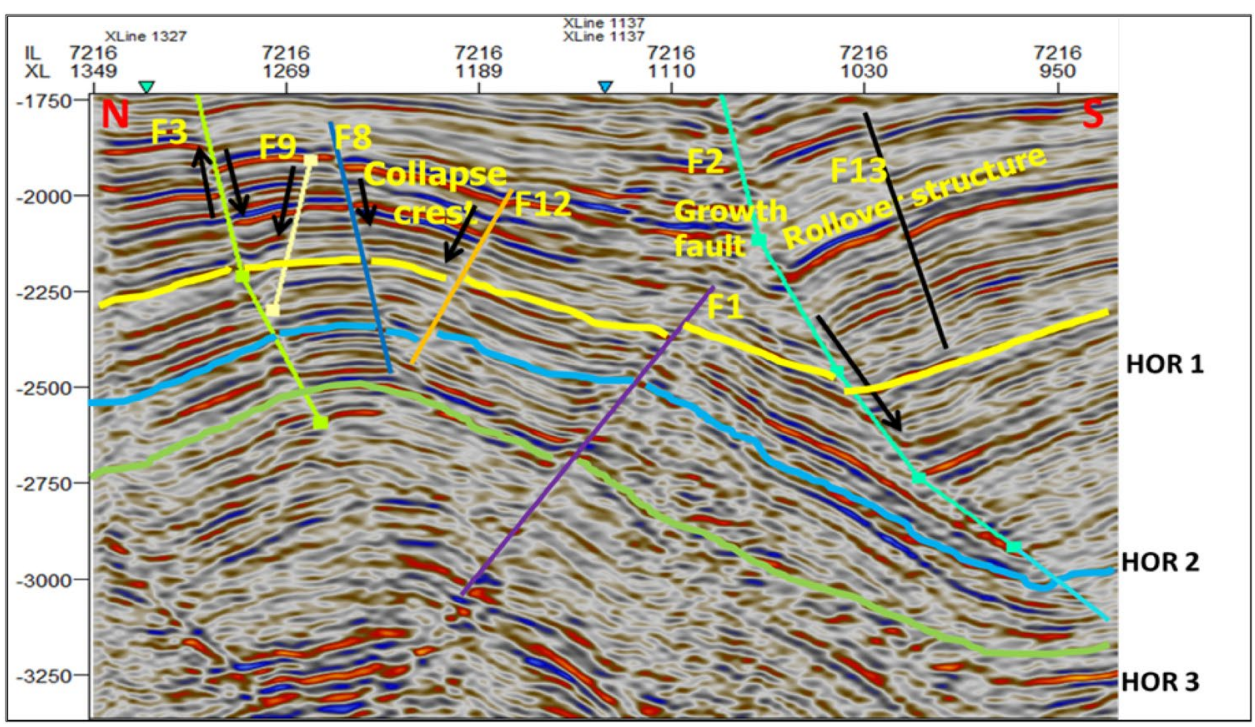


Fig. 3 Time structure map of horizon 1

Fig. 4 Composite gamma ray, deep resistivity, and density $\log$ readings in reservoir R1, well 1
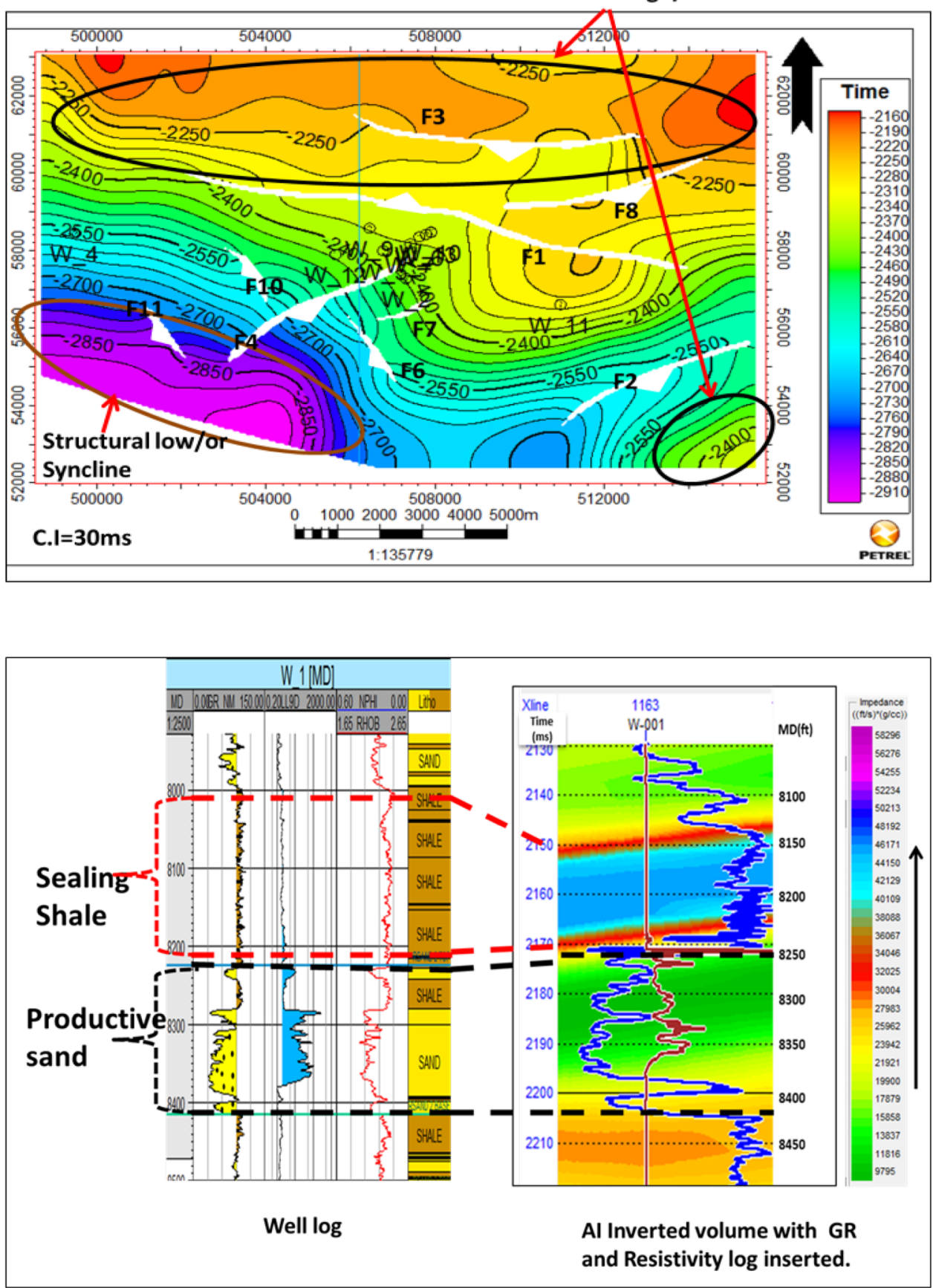

summarizing the inversion results for well 1. Figure 6a shows the delineated reservoir sand between the depths of $8250 \mathrm{ft}$ and $8415 \mathrm{ft}$. Figure $6 \mathrm{~b}$ shows a plot of the inverted acoustic impedance trace (red), log-derived AI trace (black), and resistivity trace (grey) in well 1 . A reduction in acoustic impedance and the overlain inverted AI trace values was observed within the hydrocarbon interval. These two traces overlapped, which gave credence to the level of confidence in the inversion work at the well location. Figure $6 \mathrm{c}$ shows the inverted section overlain by gamma and resistivity $\log$ (blue and red) at the well location on seismic inline 6917 which revealed that the hydrocarbon-bearing interval labelled ' $\mathrm{R} 1$ ' is characterized by low acoustic impedance (green). Low gamma ray and high resistivity readings were observed to have conformed to this low acoustic impedance interval (green).

\section{Crossplot analysis}

Crossplot analysis is carried out to determine the rock properties/attributes that better discriminate the reservoir 


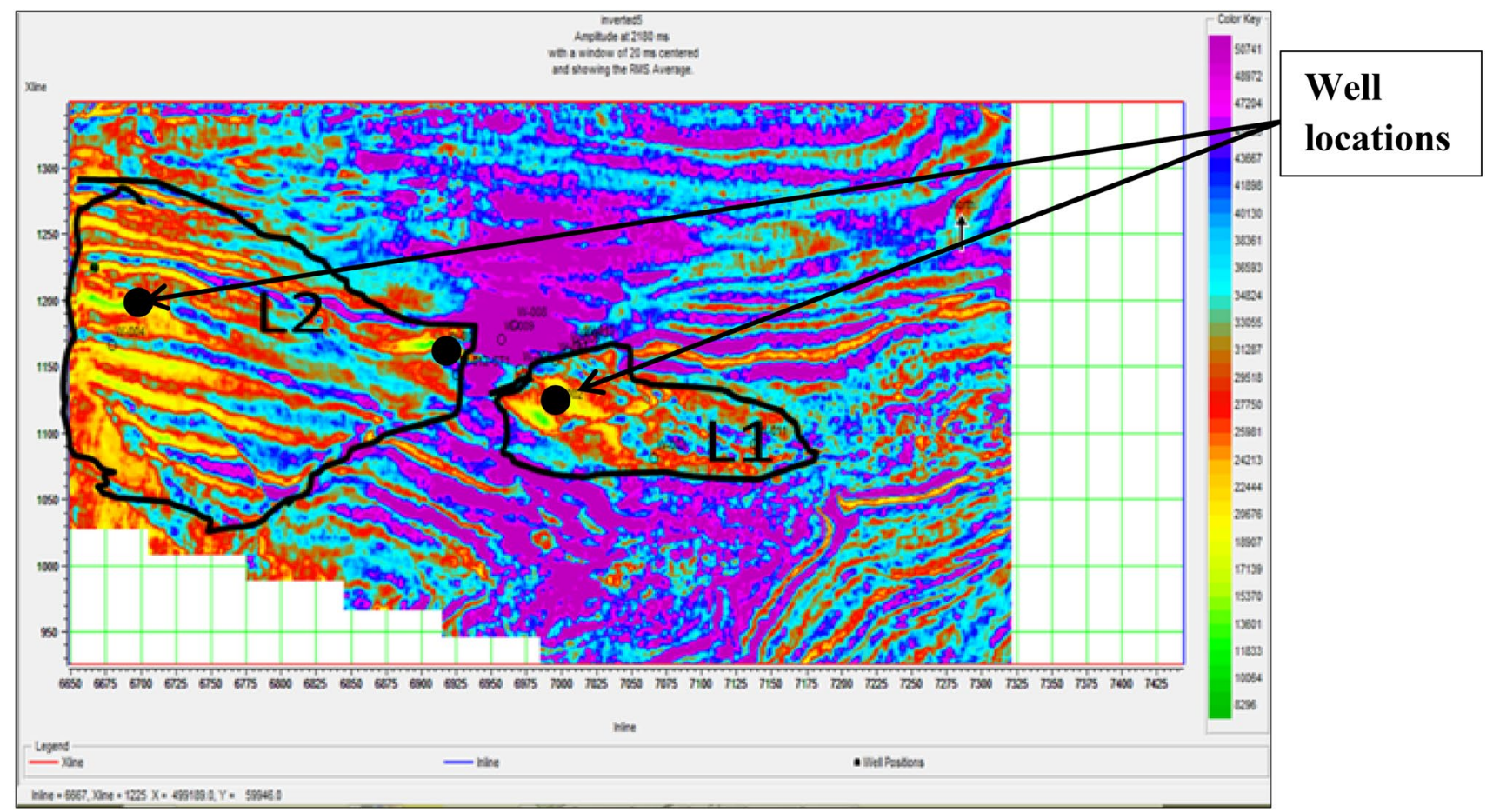

Fig. 5 Time slice $(2180 \mathrm{~ms})$ showing the distribution of acoustic impedance

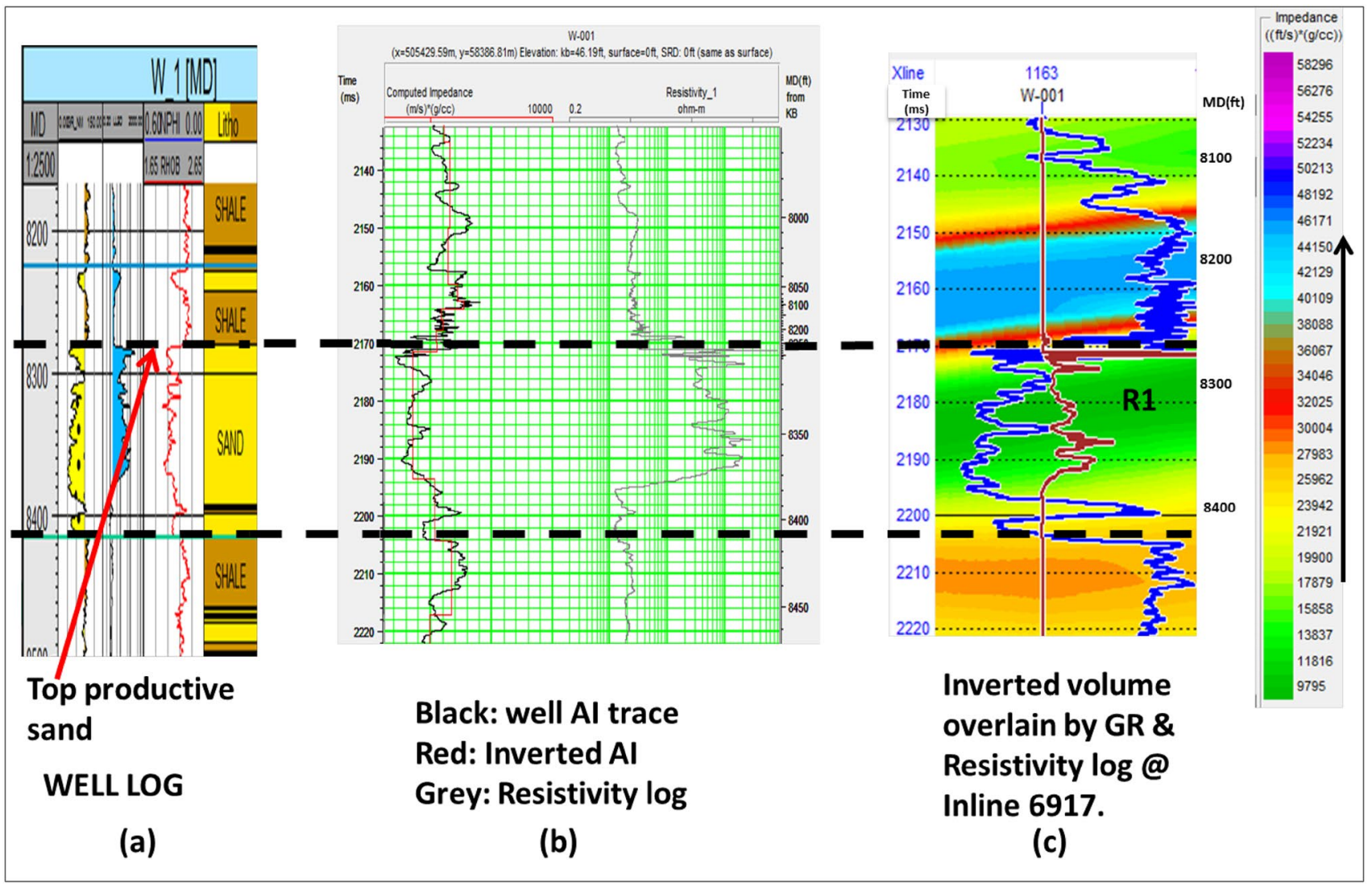

Fig. 6 Link between seismically derived acoustic impedance attribute and well logs at the productive zone in well 1 


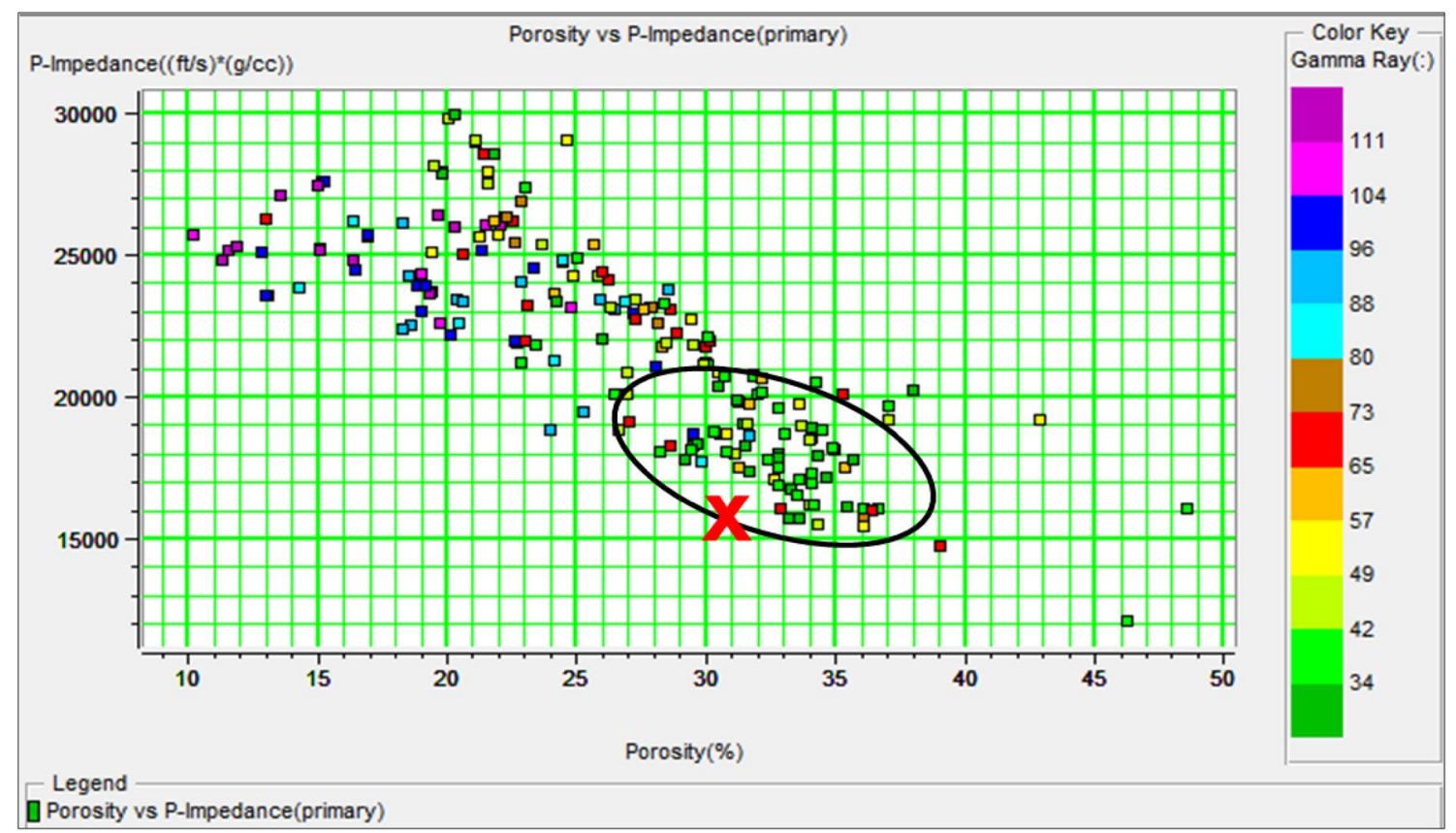

Fig. 7 Crossplot of reservoir porosity and acoustic impedance with gamma ray in reservoir R1, well 1

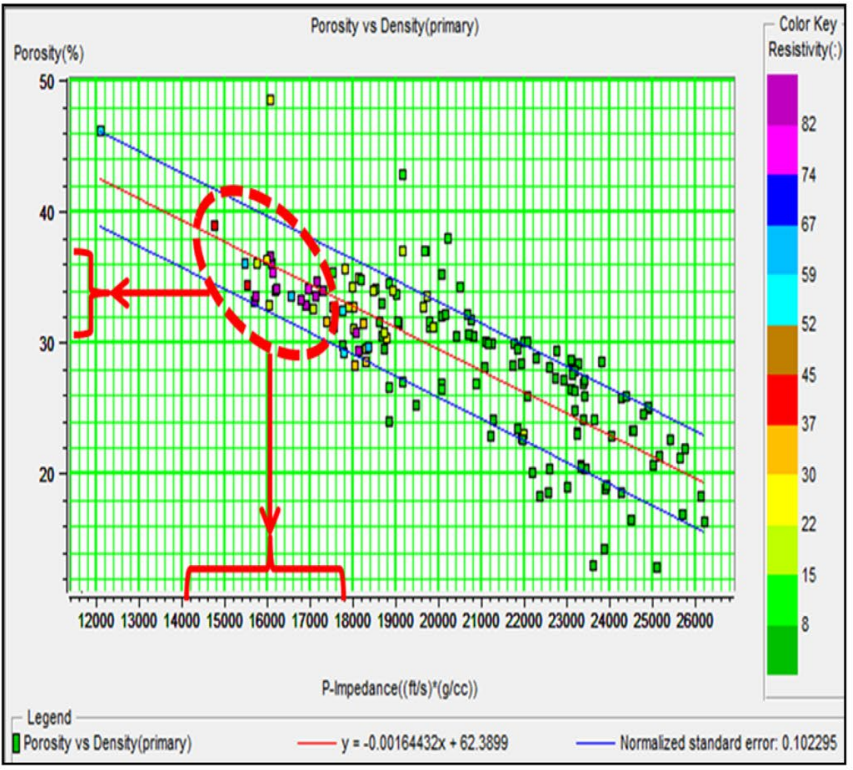

(a)

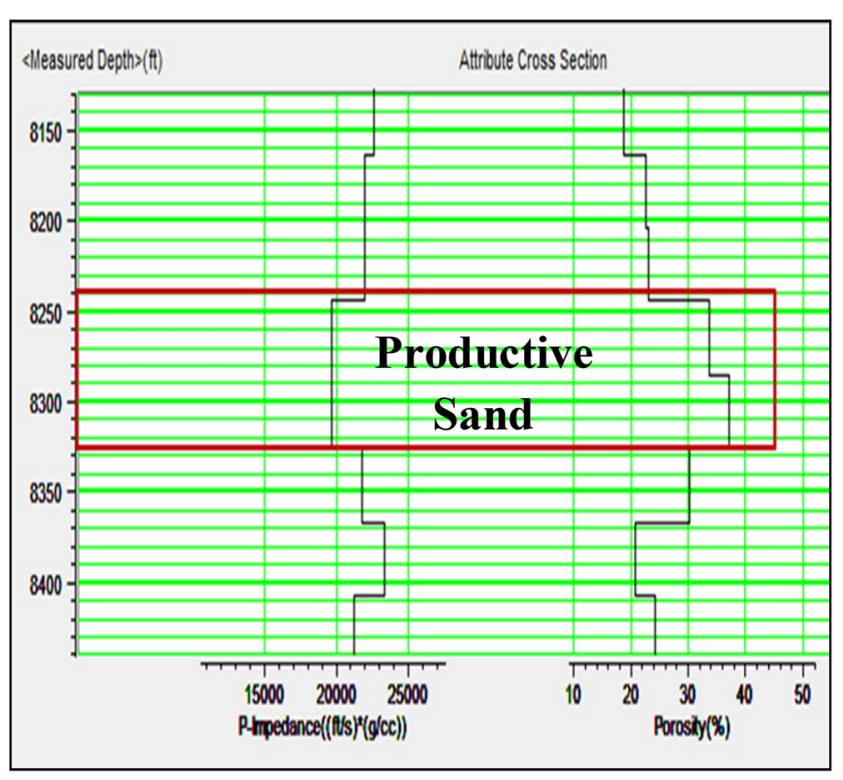

(b)

Fig. 8 a Crossplot of resistivity value in productive zone with acoustic impedance and porosity in reservoir R1, well 1. b Cross section relationship of AI and porosity at the productive zone (Reservoir R1)

(Omudu et al. 2007). Figure 7 shows the crossplot of porosity and acoustic impedance values in conjunction with gamma ray. A linear relationship was observed between the reservoir properties. An increase in porosity causes a decrease in velocity, a decrease in density, and therefore a corresponding decrease in acoustic impedance. The zone labelled ' $X$ ' shows high-porosity zones concentrated within the region of low gamma ray, which is the reservoir zone. The porosity values are in the range of 26-40\%. Figure 8 reveals the relationship between acoustic impedance, porosity, and the associated resistivity values 


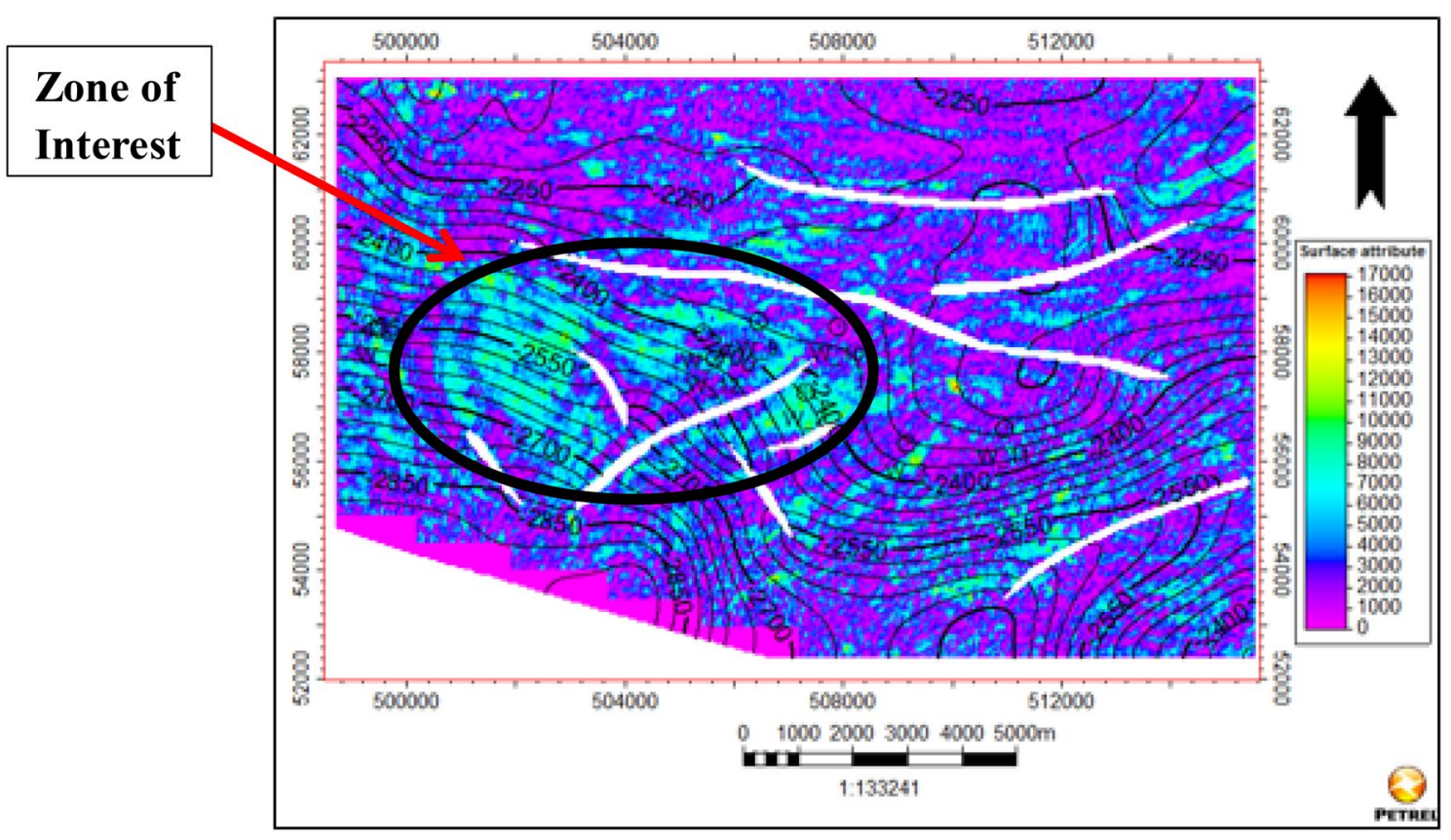

Fig. 9 Root mean square (RMS) amplitude attribute extracted on horizon 1

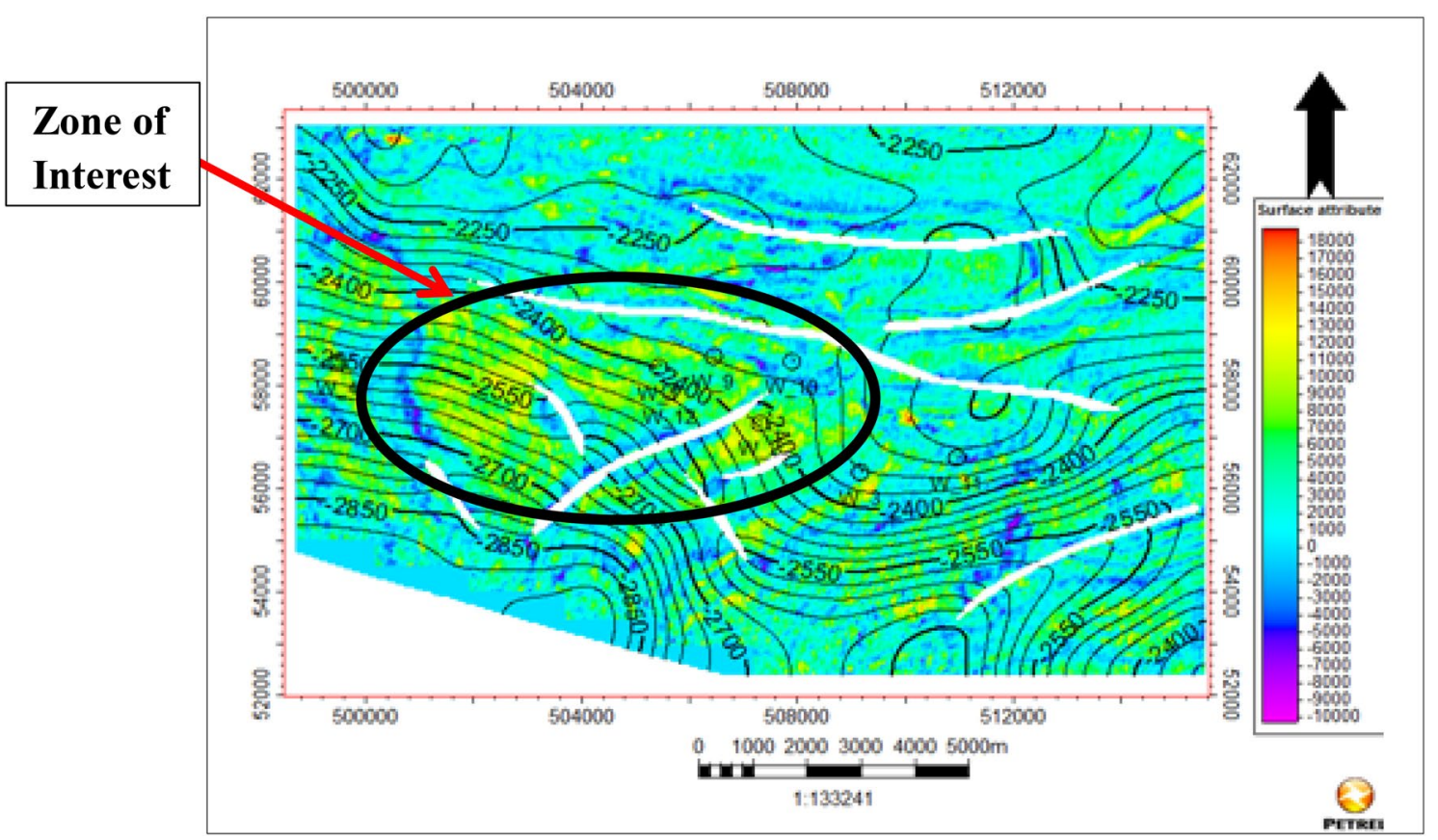

Fig. 10 Maximum amplitude attribute extracted on horizon 1

within the productive sands in well 1 . High resistivity values were observed at the region of low acoustic impedance in the range of 14,000-18,000 ft/s g/cc and high porosity values ranging from 30 to $40 \%$, which confirmed that the reservoir sand is fluid-saturated (hydrocarbon).

\section{Seismic attribute analysis}

Figures 9, 10, and 11 show the root mean square (RMS), maximum, and interval average attributes extracted on horizon 1 . These attributes were used to measure reflectivity in order to map the strongest direct hydrocarbon indicator 


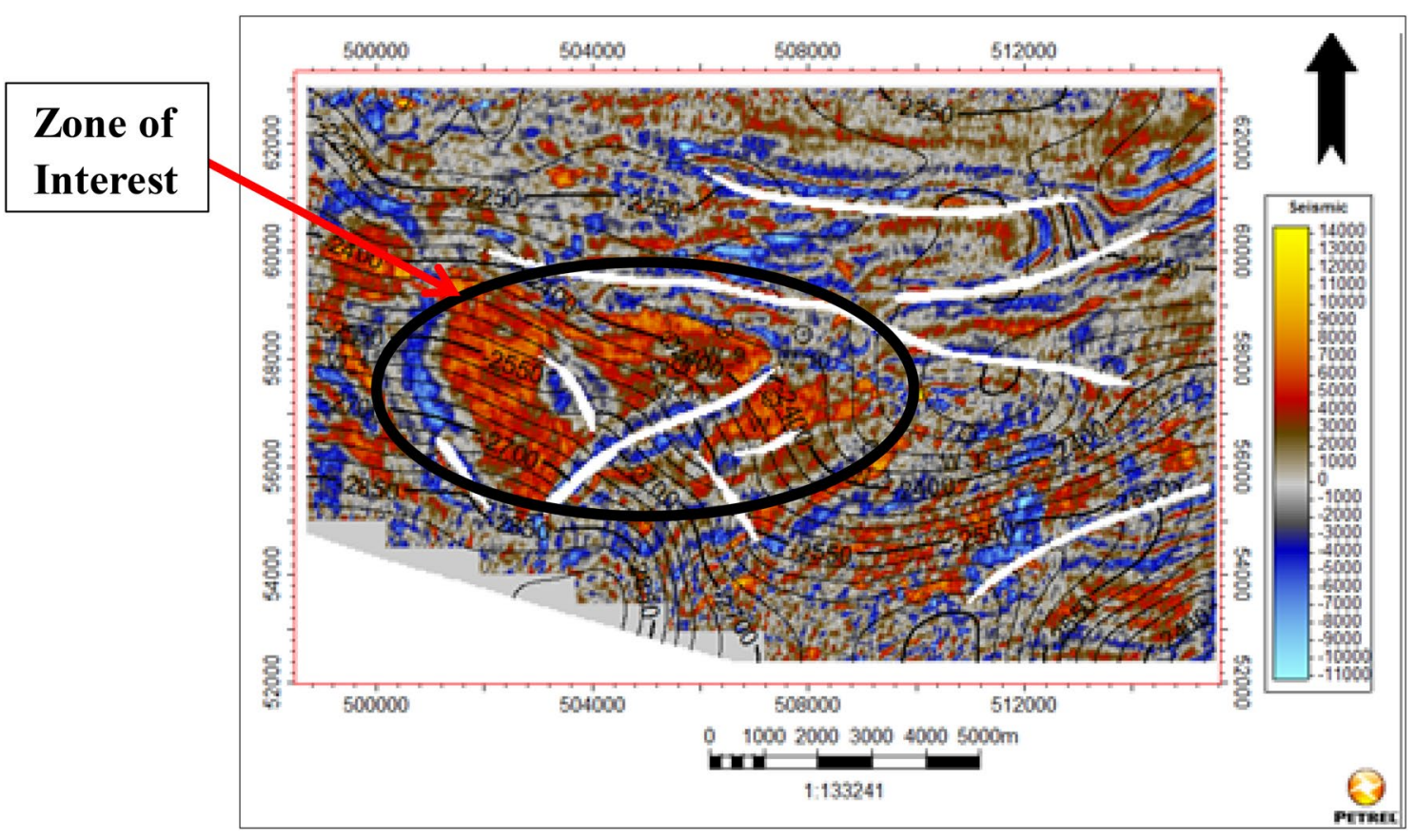

Fig. 11 Interval average arithmetic attribute extracted on horizon 1

within the zones of interest. The revealed high reflection amplitude areas are indicated by eclipse in Figs. 9, 10, and 11. These amplitudes terminated on the minor faults mapped in the area. The implication is that reservoir sandstone is concentrated in the western zone of the field and trend along the flank of the anticlinal structure. This seemingly bright spot is as a result of the presence of hydrocarbon, as the area of the observed anomaly coincides with the identified area with low acoustic impedance and high porosity on acoustic impedance slice as seen in Fig. 5. Resistivity log in well 2 located within the zone marked with eclipse shows high values corresponding to high-amplitude sand in horizon 1 .

\section{Conclusion}

Model-based seismic acoustic impedance inversion method and attribute analysis have been utilized to examine the relationship between reservoir structures, their acoustic effect, and the reservoir property distribution in 'DJ' Field, Niger Delta. The field is characterized by structural high and low features dominated by synthetic, antithetic, and growth faults, collapsed crest, and rollover anticlines. The hydrocarbon-bearing sands were identified with high porosity (25-36\%) and high resistivity. Acoustic impedance, being layer property, complements the standard seismic amplitude interpretation (Interface property) as changes in value (colour) reflect changes in lithology. Comparing the acoustic impedance slice and seismic attribute maps at the target reservoir intervals, low acoustic impedance and high reflection amplitudes (bright spot) were observed in the western and central parts of the study area which are indicative of hydrocarbon accumulation. It was observed on the maps that the hydrocarbon-bearing wells (W_4, W_12, W_2, and W_ 3 ) are located within the productive zones.

Acknowledgements The author thanks the Shell Petroleum Development Company of Nigeria Limited via the Department of Petroleum Resources for the provision of research dataset and thanks the Schlumberger and Hampson-Russell Limited for providing the software.

Open Access This article is distributed under the terms of the Creative Commons Attribution 4.0 International License (http://creativeco mmons.org/licenses/by/4.0/), which permits unrestricted use, distribution, and reproduction in any medium, provided you give appropriate credit to the original author(s) and the source, provide a link to the Creative Commons license, and indicate if changes were made.

\section{References}

Al-Shaieb Z, Hanson RE, Donovan RN, Shelton JW (1980) Petrology and diagenesis of sandstone in the Post Oak Formation (Permian), southwestern Oklahoma. J Sediment Pet 50:43-50

Avbovbo AA (1978) Tertiary lithostratigraphyof Niger Delta. Am Assoc Pet Geol Bull 62:237-241

Burst JF (1969) Diagenesis of Gulf Coast clayey sediments and its possible relation to petroleum migration. AAPG Bull 53:73-93

Doust H, Omatsola O (1990a) Niger Delta. In: Edwards JD, Santoyiossi PA (eds) Divergent and passive margin basin, vol 48. American Association of Petroleum Geologist Memoir, Yulsa, pp 201-238

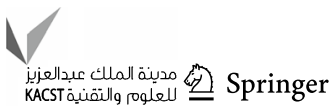


Doust H, Omatsola E (1990b) Niger Delta. In: Edwards JD, Santogrossi PA (eds) Diverdent/passive margin basins, AAPG Memoir, vol 48. American Association of Petroleum Geologist, Tulsa, pp 239-248

Edwards JD, Santogrossi PA (1990) Summary and conclusions. In: Edwards JD, Santogrossi PA (eds) Divergent/passive margin basins, AAPG Memoir, vol 48. American Association of Petroleum Geologist, Tulsa, pp 239-248

Evamy BD, Haremboure J, Kamerling P, Knaap WA, Molloy FA, Rowlands PH (1978) Hydrocarbon habitat of Tertiary Niger Delta. Am Assoc Pet Geol Bull 62:277-298

Heald MT (1956) Cementation of simpson and St. Peter sandstone in parts of Oklahoma, Arkansas and Missouri. J Geol 64:16-30

Kulke H (1995) Nigeria. In: Kulke H (ed) Regional petroleum geology of the world Part II. Gebruder Borntraeger, Berlin, pp 143-172

Lambert DO (1981) Sandstone diagenesis and its relation to petroleum generation and migration in the Niger Delta. Thesis; Doctor of Philosophy, Geology Department, Royal School of Mines, Imperial College of Science and Technology, London

Latimer R, Davison R, van Riel P (2000) An interpreter's guide to understanding and working with seismic-derived acoustic impedance data. Leading Edge 19(3):242-256

Lefeuvre FE, Wrolstad KH, Zou KS, Smith LJ, Maret JP, Nyein UK (1995) Sand-shale ratio and sandy reservoir properties estimation from seismic attributes: an integrated study. SEG Expand Abstr 95:108-110

Omudu ML, Ebeniro JO, Olotu S (2007) Optimizing quantitative interpretation for reservoir characterization: case study onshore Niger Delta. In: A paper presented at the 31st annual SPE international technical conference and exhibition in Abuja, Nigeria

Patchett JG, Coalson EB (1982) The determination of porosity in sandstone: Part two, effects of complex mineralogy and hydrocarbons. In: Paper T presented at the 1982 annual society of professional well log analysts symposium, Corpus Christi, Texas, 6-9 July

Pendrel J (2006) Seismic inversion-still the best tool for reservoir characterization. In: CSEG, recorder, pp 5-12

Pryor WA (1973) Permeability-porosity patterns and variations in some Halocene and variations in some Holocene sand bodies. AAPG Bull 57:162-189
Raymer LL, Hunt ER, Gardner JS (1980) An improved sonic transit time-to-porosity transform, paper P. Trans., 1980 Annual Logging Symposium, SPWLA, pp 1-12

Rijks EJK, Jauffred JCEM (1991) Attribute extraction: an important application in any detailed 3-D interpretation study. Lead Edge 10:11-19

Russell BH (2004) The application of multivariate statistics and neural networks to the prediction of reservoir parameter using seismic attributes. Ph.D. Dissertation, University of Calgary, Alberta

Sancevero SS, Remacre AZ, Portugal RS, Mundim EC (2005) Comparing deterministic and stochastic seismic inversion for thin-bed reservoir characterization in a turbidite synthetic reference model of Campos Basin, Brazil. Lead Edge 24(11):1094-1179

Sayers C, Chopra S (2009) Special session: rock physics. Lead Edge 28:15-16

Schlumberger (2008) Space-adaptive inversion. Reading Between the Lines. Oilfield Review. http://www.slb.com/content/services/ seismic/reservoir/inversion/space_adaptive.asp. Accessed 22 Apr 2008

Soubotcheva N (2006) Reservoir property prediction from well-logs, VSP and multicomponent seismic data. Pikes peak heavy oilfield. Saskatchewan. M.Sc Thesis. Department of Geology and Geophysics University of Calgary, Alberta

Sukmono S (1999) An introduction to seismic reservoir analysis, pp 2-3

Veeken PCH, Rauch M, Gallardo R, Guzman E, Vila RV (2002) Seismic inversion of the Fortuna National 3D survey, Tabasco, Mexico. First Break 20(5):287-294

Weber KJ, Daukoru EM (1975) Petroleum geology of the Niger Delta. In: Proceedings of the ninth world petroleum congress, vol 2. Geology, Applied Science Publishers, Ltd., London, pp 210-221

Publisher's Note Springer Nature remains neutral with regard to jurisdictional claims in published maps and institutional affiliations. 